\title{
Peristomal Dermatitis: Treatment with Green Banana Peel (Musa sapientum) Powder
}

\section{Dermatite periestomal: tratamento com pó de casca de banana verde (Musa sapientum)}

\author{
Ana Cristina da Silva ${ }^{1}$ Isabella Stephanie Simões ${ }^{1}$ Geraldo Magela Salomé ${ }^{1}$ \\ Dênia Amélia Novato Castelli von Atzingen ${ }^{1}$ Adriana Rodrigues dos Anjos Mendonça1(0)

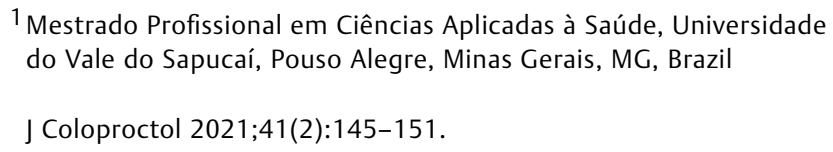 \\ Address for correspondence Adriana Rodrigues dos Anjos Mendonça, \\ MD, Universidade do Vale do Sapucaí, rua Otto Piffer 185, apto. 202, \\ Pouso Alegre, Minas Gerais, MG, 37553-629, Brazil \\ (e-mail: drijar@hotmail.com).
}

\begin{abstract}
Objective To develop green banana peel (Musa sapientum) powder for the treatment of peristomal dermatitis, and to evaluate its effectiveness and healing time.

Methods A clinical, analytical and longitudinal study. In total, 44 volunteers of both genders, aged $>18$ years, with intestinal ostomy, who presented peristomal dermatitis, participated in the research. The sample was divided into two groups: the study group used a powder containing $10 \%$ of green banana peel, and the control group used ostomy powder. The research was approved by the Ethics in Research Committees (Comitês de Ética em Pesquisa, CEP, in Portuguese) under opinion $n^{\circ} 2.381 .904$.

Results The healing time of the study group was shorter than that of the control group ( $p=0.022)$. To analyze the results, we used the two-sample $t$-test (mean days

Keywords

- ostomy

- phytotherapeutic

- irritating dermatitis

\section{Resumo}

\section{Palavras-chave}

- estomia

- medicamentos fitoterápicos

- dermatite irritante until healing for both study groups).

Conclusion The powder containing $10 \%$ of green banana peel was developed, and effective healing of the peristomal dermatitis was observed. Compared to the ostomy powder, it presented a shorter healing time.

Objetivo Desenvolver o pó composto da casca da banana verde (Musa sapientum) para o tratamento de dermatite periestomal, e avaliar a eficácia e o tempo de cicatrização.

Métodos Estudo clínico, analítico e longitudinal. Participaram da pesquisa 44 voluntários, de ambos os gêneros, maiores de 18 anos, com estomias intestinais, e que apresentavam dermatite periestomal. A amostra foi dividida em dois grupos: o grupo de estudo usou um pó que continha $10 \%$ de casca de banana verde, e o grupo de controle usou pó para estomia. A pesquisa foi aprovada pelos Comitês de Ética em Pesquisa (CEP), sob o parecer $n^{\circ} 2.381 .904$.
\end{abstract}

received

August 27, 2020

accepted

January 15, 2021
DOI https://doi.org/

10.1055/s-0041-1730389.

ISSN 2317-6423. (c) 2021. Sociedade Brasileira de Coloproctologia. All rights reserved.

This is an open access article published by Thieme under the terms of the Creative Commons Attribution-NonDerivative-NonCommercial-License, permitting copying and reproduction so long as the original work is given appropriate credit. Contents may not be used for commercial purposes, or adapted, remixed, transformed or built upon. (https://creativecommons.org/ licenses/by-nc-nd/4.0/)

Thieme Revinter Publicações Ltda., Rua do Matoso 170, Rio de Janeiro, RJ, CEP 20270-135, Brazil 
Resultados O tempo de cicatrização do grupo de estudo foi menor do que o do grupo de controle $(p=0.022)$. Para a análise dos resultados, empregou-se o teste $t$ para duas amostras (média de dias de cicatrização de ambos os grupos).

Conclusão Desenvolveu-se o pó contendo 10\% de casca de banana verde, e observouse cicatrização eficaz da dermatite periestomal. Em comparação com o pó para estomia, apresentou tempo menor até a cicatrização.

\section{Introduction}

The word stoma, comes from the Greek stóma, meaning "mouth" or "opening", and it is used to name a surgical intervention to communicate a hollow organ with the external environment. ${ }^{1}$

The main causes of intestinal stoma are colorectal neoplasms, primarily abdominal trauma, and inflammatory bowel diseases. $^{2}$

In $2018,^{3}$ it was estimated that, in the State of Minas Gerais (MG), Brazil, for every 100 thousand inhabitants, the incidence of malignant neoplasms of the colon and rectum as the primary location would reach 1,510 new cases among men and 1,650 among women. In the state capital, the incidence would be of 310 among men and 390 cases among women for every 100 thousand inhabitants.

The stoma can seriously limit the quality of life of the patients who are forced to live with this new condition, which can be a mutilating and traumatic event, causing emotional and physical damage. ${ }^{4}$

The type of complication most commonly found in the literature is peristomal dermatitis, with an emphasis on dermatitis associated with moisture, which results from exposure of the skin to intestinal or urinary effluents. ${ }^{5}$

In a study ${ }^{6}$ performed in Denmark in 2006, the authors found that $92 \%$ of the patients had an intestinal stoma, and $45 \%$ had peristomal skin disorders.

Peristomal dermatitis may have an irritating origin, due to the contact of proteolytic enzymes present in the effluent, which cause a chemical reaction and corrosion. The alkaline $\mathrm{pH}$ of watery stools, in the case of ileostomy, favors a change in the defense mechanisms of the skin, which develops erythema, hemorrhage, and pain. In colostomy, although the $\mathrm{pH}$ is less harmful to the skin, the continuous contact when leaking causes irritation and, consequently, dermatitis. $^{7}$

Powdered synthetic resin is one of the recommended protective skin barriers as an adjunctive therapy in the care for people with stomas. It is indicated in cases of peristomal moisture-associated dermatitis to promote a better adaptation of the adhesive barrier. ${ }^{8}$

The peel and pulp of the banana have been identified as potent antioxidants, and they have a high dopamine content. $^{9}$

Green banana (Musa sapientum) is one of the most consumed fruits in the world; it originated in Asia, and it is cultivated in tropical countries. ${ }^{10}$
The green banana extract not only increases the density of the mucosa, but also increases the incorporation of thymidine into the DNA, promoting cell multiplication, which potentiates the healing effects of the extract. ${ }^{11}$

In a randomized study ${ }^{12}$ performed with rats, the authors found that there was an increase in the percentage of vascular proliferation in a discrete to marked amount, in lesions in which the gel composed of the green burro banana peel was used, with significance regarding the acute inflammatory reaction. The best response to the healing process was obtained using a gel composed of $10 \%$ of green banana peel, ${ }^{13}$ when partial re-epithelialization and reduction of the wound area was demonstrated. ${ }^{14}$

Based on the assumption of efficacy in the healing process of open wounds, the use of a powder composed of $10 \%$ of green banana peel in peristomal dermatitis was assessed, mainly due to the ease of production of the powder and its low cost compared to that of products already available in the market for this purpose. Considering that such injuries need a product that does not interfere with the adhesion of the pouching system plate, and that the products available for sale are in the form of powders, we decided to use the manipulated green banana skin in powder form.

Thus, the present study aimed to develop the powder containing green banana peel and evaluate its effectiveness regarding the healing time inperistomal dermatitis.

\section{Methods}

The present research followed the ethical principles of resolution $n^{\circ} 466$, of the Brazilian National Health Council (Conselho Nacional de Saúde - CNS, in Portuguese), which defines the ethical procedures for research in human beings. The work was initiated after approval by the Ethics in Research Committee of Universidade do Vale do Sapucaí, under opinion $n^{\circ}$ 2.381.904/CAAE: 57362316.8.0000.5102.

Data collection was performed at the Ostomy Care Service (Serviço de Atenção à Saúde de Pessoa Ostomizada - SASPO, in Portuguese), which is part of the Brazilian Unified Health System (Sistema Único da Saúde - SUS, in Portuguese), also known as Stomatherapy Outpatient Clinic, located in the city of Pouso Alegre (MG).

The SASPO provides specialized nursing care and the distribution of collecting supplies to 25 municipalities in the region. 
The present was a clinical, analytical and longitudinal study conducted between February 2018 and July 2019 using convenience sampling.

The sample was composed of 44 participants with intestinal stoma who had peristomal dermatitis diagnosed after a consultation at the service. They were divided into two groups: the study group used the powder containing $10 \%$ of green banana peel, and the control group used ostomy powder.

The ostomy powder, a product manufactured and sold by international laboratories and offered by the SUS, is composed of synthetic resin.

The study included people with intestinal ostomy, of both genders, aged $>18$ years, who had peristomal dermatitis and agreed to participate by signing the informed consent form (ICF).

Minors with urinary stomas, who had any known allergy to the product and who refused to participate in the study were not included.

Participants who did not return to the consultation for the evaluation of the dermatitis and those who did not follow the relevant guidelines for the use of the powder were excluded.

The powder was obtained from the peels of green bananas of the species $M$. sapientum, according to the scale of Von Loesecke, ${ }^{15}$ which classifies the ripeness of bananas by the color of their rind.

Green bananas were used due to the alteration of the properties of the fruit during the ripening process, and they were selected by the researcher directly from the producer, to guarantee the ideal quality of the fruit.

The bananas were sent to the Botany Laboratory at Universidade do Vale do Sapucaí (UNIVÁS) for processing and final preparation.

The peels were separated from the pulp, washed, and placed on a drying bench. After total dehydration, they were ground and then crushed with the aid of a pestle and mortar, and sifted using a voile strainer to obtain a fine and homogeneous powder.

For better handling of the final product, gelatin was then used, which was also crushed in the pestle and morter and sieved. The final product, which was stored in 30-mm dropper bottles, contained $45 \%$ of gelatin, $45 \%$ of carboxymethyl cellulose, and $10 \%$ of the green banana peel powder.

For the classification of peristomal dermatitis, the SACS (Convatec, Inc., Reading, Berkshire, UK) instrument was used to assess the time in days it took for the lesion to heal according to the number of affected quadrants in each appointment after using the powder.

All participants who presented dermatitis after a pilot test were classified as L2 (erosive lesion). ${ }^{16}$

For the distribution of the groups, we estimated the number of enrollments to the study that could occur during the proposed data collection period. After 22 people had enrolled to form the study group, the control group, which was provided by the State, was later formed.

All participants received free bottles of the powder, and both groups were intructed to apply it at home using the same method.
After and explanation about the research, the subjects agreed to particpate, signed the ICF, and attended a consultation previously scheduled with the stoma nurse, according to the routine of the service.

The SASPO has an exclusive office with a bathroom adapted for ostomy patients, according to directive $n^{\circ}$ 400/2009 of the Brazilian Ministry of Health (-Figure 1).

To proceed with data collection, the participants were evaluated in the first consultation. The type of complication related to the stoma was identified. With the permission of the patients, the cases of dermatitis were photographed, classified according to the SACS, the conduct was recorded in the medical record of the type of collecting supply and adjuvant therapy (powder) prescribed.

The powder was applied by the researcher during the first consultation after the evaluation of the dermatitis.

Accompanied by a family member or caregiver, the participants were instructed about the research and about how to care for the stoma, for the correct use of the product at home when changing the collection bag, which would occur every four days on average, until the reassessment in the service.

Data were tabulated in Microsoft Excel (Microsoft Corp., Redmond, WA, US), version 2016, spreadsheets and subjected to statistical analysis using measures of central tendency for the quantitative variables and absolute and relative frequency for the categorical variables.

The Minitab (Minitab, LLC, State College, PA, US) software, version 18.1, and the Statistical Package for the Social Sciences (SPSS, IBM Corp., Armonk, NY, US), version 22.0, were employed. The level of significance was set at $5 \%(p$ $<0.05)$. For the analysis of the results, we used the twosample $t$-test to study whether there was a difference in the mean healing time between the two study groups.

\section{Results}

A total of 95 patients were evaluated, 49 of whom had dermatitis at the time of the consultation.

Both study groups had the same characteristics, such as diverse age range, most of them with stomas from intestinal neoplasms, with no fixed standardization of the interval between consultations due to the same logistical difficulties, all had moisture-associated dermatitis, and the surgeries were performed in the same hospitals. Some surgeries were elective, and others were emergency procedures.

In the control group, there were initially 27 participants, but 5 were excluded according to the aforementioned criteria. One particpant did not follow the guidelines for the change of the collection bag and application of the powder, and the others missed the subsequent consultation; therefore, the study group was composed of 22 participants.

By the second appointment, the dermatitis showed $100 \%$ of healing in most of the participants In the control group, 4 participants required 3 consultations until total healing of the dermatitis was observed; in the study group, 3 patients required 2 consultations, and 1 required 4 . Data on the number of consultations required until total healing, as 


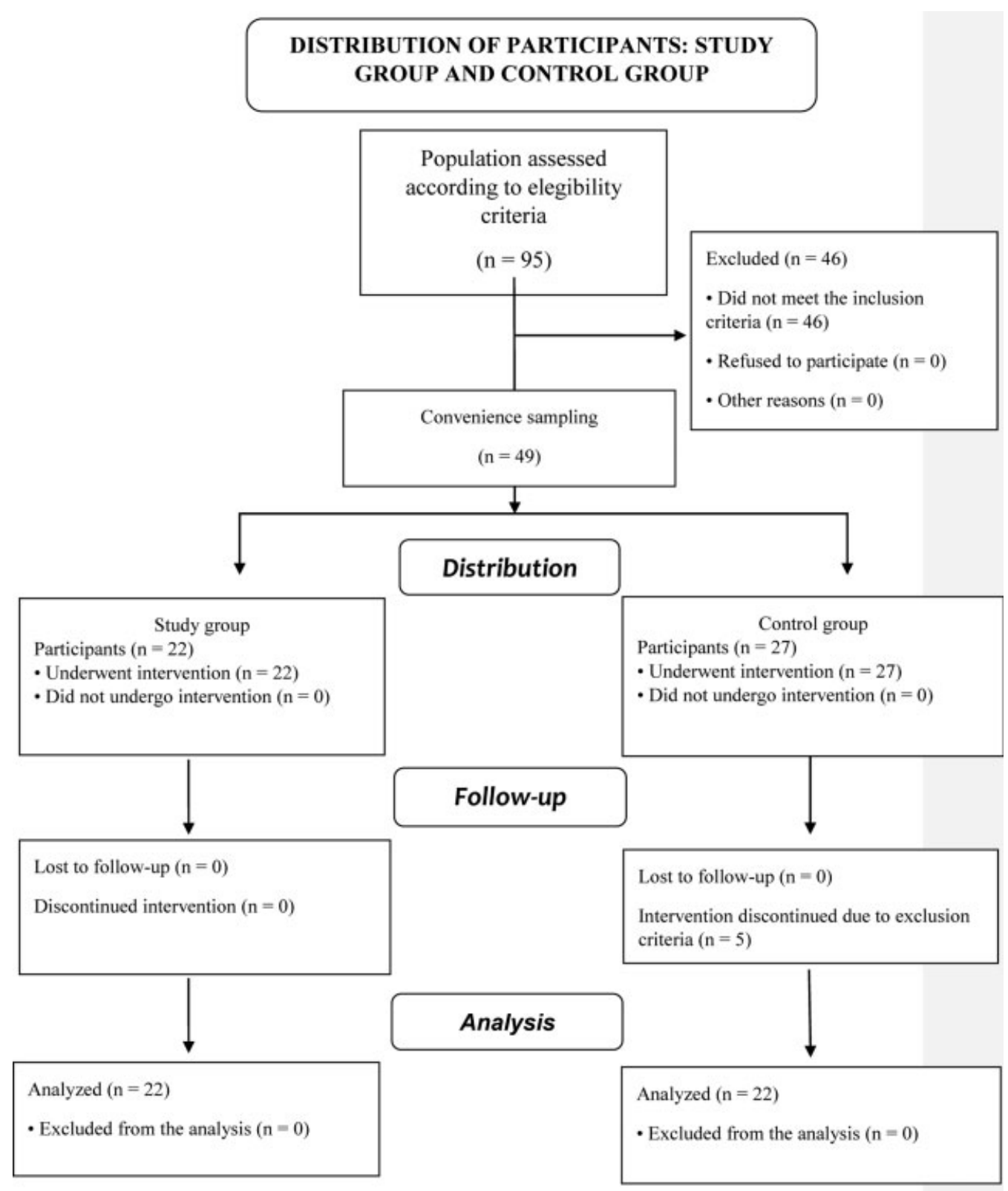

Fig. 1 CONSORT 2010 Flow Diagram.

well as on the gender and age of the participants, is presented in (Boxes 1 and 2). The study group was composed of 99\% of men, with an average age of 62.4 years, and the control group was composed of $56 \%$ of men, with an average age of 59 years.

The evaluation of the healing time for the study group was measured in days, and this period was shorter than that of the control group ( $p=0.022$; Box3).

\section{Discussion}

When analyzing the data, we could identify effective healing of the peristomal dermatitis in the study group. The participants also reported immediate pain relief in the region of the injury, comfort after use, and skin protection. The time of permanence of the pouching system did not differ between the groups.
Adjuvant products such as skin protective barriers, which are available for sale in the market, as well as collecting supplies, which are indicated for the treatment of stomarelated complications, according to some guidelines aimed at this care, have a recommendation with a significant level of evidence (Strength of evidence $=\mathrm{B}$ ), by contributing to a better quality of life and rehabilitation for the ostomized individual. $^{17}$

Based on the results of the present study the powder composed of $10 \%$ green banana peel is an excellent option of adjuvant product for the management of peristomal dermatitis,because, in addition to its effectiveness and shorter healing time in relation to the ostomy powder, its production is low-cost. It even demonstrated the ability to absorb moisture, given the durability (average of four days) of the 
Box 1 Classification of the dermatitis in the study group according to the SACS intrument

\begin{tabular}{|l|l|l|l|l|l|l|}
\hline Participants (P) & Gender & Age (years) & $1^{\text {st }}$ SACS collection & $2^{\text {nd }}$ SACS collection & $3^{\text {rd }}$ SACS collection & $\begin{array}{l}4^{\text {th }} \text { SACS } \\
\text { collection }\end{array}$ \\
\hline P1 & Male & 82 & L2 TII TIII & $100 \%$ healing & & \\
\hline P2 & Male & 65 & L2 TV & L2 TII TIII TIV & L2 TII TIII & $100 \%$ healing \\
\hline P3 & Male & 66 & L2 TV & $100 \%$ healing & & \\
\hline P4 & Male & 62 & L2 TV & $100 \%$ healing & & \\
\hline P5 & Male & 73 & L2 TV & $100 \%$ healing & & \\
\hline P6 & Male & 61 & L2 TV & $100 \%$ healing & & \\
\hline P7 & Male & 63 & L2 TI TIII TIV & $100 \%$ healing & & \\
\hline P8 & Male & 52 & L2 TI TIII TIV & L2 TIV & $100 \%$ healing & \\
\hline P9 & Male & 34 & L2 TV & L2 TI TII & $100 \%$ healing & \\
\hline P10 & Male & 67 & L2 TV & $100 \%$ healing & & \\
\hline P11 & Male & 59 & L2 TII TIII TIV & L2 TIV & $100 \%$ healing & \\
\hline P12 & Female & 52 & L2 TV & $100 \%$ healing & & \\
\hline P13 & Male & 66 & L2 TV & $100 \%$ healing & & \\
\hline P14 & Female & 54 & L2 TV & $100 \%$ healing & & \\
\hline P15 & Male & 81 & L2 TV & $100 \%$ healing & & \\
\hline P16 & Male & 67 & L2 TV & $100 \%$ healing & & \\
\hline P17 & Male & 59 & L2 TV & $100 \%$ healing & & \\
\hline P18 & Male & 61 & L2 TV & $100 \%$ healing & & \\
\hline P19 & Male & 52 & L2 TV & $100 \%$ healing & & \\
\hline P20 & Male & 73 & L2 TV & L2 TI TIV & $100 \%$ healing & \\
\hline P21 & Male & 60 & L2 TV & $100 \%$ healing & & \\
\hline P22 & Male & 65 & L2 TIII TIV & $100 \%$ healing & & \\
\hline
\end{tabular}

adhesive base of the collectiong equipment on the participants' skin.

There is no description in the literature of the use of phytotherapeutic cutaneous protective barriers in powder form, despite the advances in the studies on phytotherapeutic medicines.

The optimization of material resources, including the equipment and adjuvants used, is paramount for the effective care for ostomy patients. The use of technology in health must encompass an evaluation of the costs, but it must also guarantee the principles championed by the SUS. ${ }^{18}$

We opted for the concentration of $10 \%$ of green banana peel powder because previous experimental works performed in rats and humans obtained satisfactory results with this concentration. ${ }^{14}$ The vehicles used for the final composition of the powder were chosen by composing powders for ostomies.

The products that offer protection to the skin protectors are sold in the form of powders, pastes and plates, and they contain hydrocolloids such as gelatin, pectin, carboxymethyl cellulose and polysobutylene. The powder is specifically indicated for wet lesions, for it contributes to the protection and fixation of the adhesive bases of the ostomy pouching system. ${ }^{19}$
In a study ${ }^{13}$ analyzing the healing of wounds by second intention in rats and using a gel containing $10 \%$ of banana, the desired epithelialization was achieved.

It is also noteworthy that concentrations of the gel at $10 \%$ have an anti-inflammatory effect on the injured tissue and stimulate healing when compared to other gels without this active ingredient. ${ }^{14}$

The use of the gel based on banana extract in chronic leg wounds demonstrated a reduction of antimicrobial activity of up to $99 \%$ in $80 \%$ of the cases, which shows its efficacy in the management of these lesions. ${ }^{20}$

The declaration of rights of the person with an ostomy states that the ostomy patient must have unrestricted access to the variety of accessible ostomy products. ${ }^{21}$

It is essential that any equipment or product prescribed for such complications offers resolvability and reliability to the patient, given the emotional changes caused by the condition of being ostomized, as already mentioned.

The SUS directive $n^{\circ} 400 / 2009$ establishes as attributions of the services dedicated to the care of ostomized people the provision of specialized assistance, in terms of assessing the general biopsychosocial needs of the individual, their family, and the specific needs related to ostomy and peristomal dermatitis, which include the prevention and treatment of 
Box 2 Classification of the dermatitis in the control group according to the SACS instrument

\begin{tabular}{|c|c|c|c|c|c|}
\hline Participants (P) & Gender & Age (years) & $1^{\text {st }}$ SACS collection & $2^{\text {nd }}$ SACS collection & $\begin{array}{l}3^{\text {rd }} \text { SACS } \\
\text { collection }\end{array}$ \\
\hline P1 & Male & 70 & L2 TV & $100 \%$ healing & \\
\hline P2 & Male & 62 & L2 TV & L2 TIV & $100 \%$ healing \\
\hline P3 & Male & 60 & L2 TV & L2 TIII TIV & $100 \%$ healing \\
\hline P4 & Male & 74 & L2 TII TIII & $100 \%$ healing & \\
\hline P5 & Male & 42 & L2 TII TIII & $100 \%$ healing & \\
\hline P6 & Female & 75 & L2 TIII & $100 \%$ healing & \\
\hline P7 & Female & 61 & L2 TV & L2 TII TIII & $100 \%$ healing \\
\hline P8 & Male & 44 & L2 TV & $100 \%$ healing & \\
\hline P9 & Male & 82 & L2 TV & $100 \%$ healing & \\
\hline P10 & Female & 69 & L2TI & $100 \%$ healing & \\
\hline P11 & Female & 59 & L2 TV & L2 TI TIII TIV & $100 \%$ healing \\
\hline P12 & Female & 43 & L2 TII TIII & $100 \%$ healing & \\
\hline P13 & Female & 74 & L2 TV & $100 \%$ healing & \\
\hline P14 & Female & 41 & L2 TV & $100 \%$ healing & \\
\hline P15 & Male & 52 & L2 TV & $100 \%$ healing & \\
\hline P16 & Female & 65 & L2 TV & $100 \%$ healing & \\
\hline P17 & Female & 51 & L2 TV & $100 \%$ healing & \\
\hline P18 & Male & 59 & L2 TI TIII TIV & $100 \%$ healing & \\
\hline P19 & Female & 69 & L2 TV & $100 \%$ healing & \\
\hline P20 & Male & 53 & L2 TV & $100 \%$ healing & \\
\hline P21 & Male & 48 & L2 TV & $100 \%$ healing & \\
\hline P22 & Male & 49 & L2 TV & $100 \%$ healing & \\
\hline
\end{tabular}

Box 3 Average healing time of peristomal dermatitis

\begin{tabular}{|l|l|l|l|}
\hline & $\begin{array}{l}\text { Participants } \\
\text { (N) }\end{array}$ & $\begin{array}{l}\text { Average } \\
\text { healing } \\
\text { time } \\
\text { (days) }\end{array}$ & $\begin{array}{l}\text { Healing time } \\
\text { (days; standard } \\
\text { deviation) }\end{array}$ \\
\hline Study group & 22 & 12.77 & 9.27 \\
\hline $\begin{array}{l}\text { Control } \\
\text { group }\end{array}$ & 22 & 19.5 & 12 \\
\hline p-value & $\mathbf{0 . 0 2 2}$ & \multicolumn{2}{|l}{} \\
\hline
\end{tabular}

complications, as well as the prescription of collection equipment and adjuvants. ${ }^{22}$

The results of the present study revealed that the powder not only provided effective healing, but also reduced tissue repair time, without compromising the adhesiveness of the collection plate; another advantage is that the powder is easy to produce.

Due to its high productivity an low cost in the most diverse regions of the Brazil, the $M$. sapientum banana is an accessible raw material.

The hydrocolloids added to the final product also have reasonable costs, and are used on a large scale in the food industry.
With its easy production, low cost and effectiveness, the green banana peel powder is an important option in the care for ostomies, especially when considering the high cost of the imported industrialized products for the same purpose and the difficulty in accessing them by patients who live in remote locations. Due to its easy application, it can also be used in hospitals, outpatient facilities, and at home by the patients themselves.

\section{Conclusion}

The powder composed of $10 \%$ of green banana peel of the $M$. sapientum species showed excellent results in the healing of peristomal dermatitis in patients with intestinal ostomy. Compared to the ostomy powder, it presented a shorter healing time.

Conflict of Interest

The authors have no conflict of interests to declare.

\section{References}

1 Habr-Gama A, Araújo SEA. Estomas Intestinais: Aspectos Conceituais e Técnicos. In: Santos VLCG, Cesaretti IUR. Assistência em estomaterapia: Cuidando do Ostomizado. São Paulo (SP): Atheneu; 2000:39-54 
2 Baykara ZG, Demir SG, Karadag A, et al. A multicenter, retrospective study to evaluate the effect of preoperative stoma site marking on stomal and peristomal complications. Ostomy Wound Manage 2014;60(05):16-26

3 Ministério da Saúde (BR) Instituto Nacional de Câncer: Estimativa de casos novos de câncer colorretal. Rio de Janeiro - RJ, INCA 2018

4 Fernandes RM, Miguir ELB, Danoso TV. Perfil da clientele estomizada residente no município de Ponte Nova, Minas Gerais. Rev Coloproct 2011;30(04):385-392

5 Nunes MLG, Santos VLCG. Instrumentos de avaliação das complicações da pele periestoma: revisão integrativa. Aquivan 2018;18 (02):477-491

6 Herlufsen P, Olsen AG, Carlsen B, et al. Study of peristomal skin disorders in patients with permanent stomas. Br J Nurs 2006;15 (16):854-862

7 Cesaretti IUB. Dermatite periestoma: da etiologia ao tratamento e assistência de enfermagem. Acta Paul Enferm 1997;10(02):80-87

8 Secretaria do Estado da Saúde de Minas Gerais. Linha de Cuidados da Pessoa Estomizada. Borges EL, Ribeiro MS In: Unidade 2 p. 23. Belo Horizonte: SES - MG; 2015 (confirmar)

9 Kanazawa K, Sakakibara H. High content of dopamine, a strong antioxidant, in Cavendish banana. J Agric Food Chem 2000;48 (03):844-848

10 Mota RV, Lajolo FM, Cordenunsi BR. Composição em carboidratos de algumas cultivares de banana (musa spp) durante o amadurecimento. Food Sci Technol (Campinas) 1997;17(02):94-97

11 Novak FR, de Almeida JA, de Souza e Silva R. Casca de banana: uma possível fonte de infecção no tratamento de fissuras mamilares. J Pediatr (Rio J) 2003;79(03):221-226

12 Von Atzingen DANCCasca da Musa sapientum verde na cicatrização de ferida operatória em ratos. Tese de doutorado - Universidade Federal de São Paulo - Escola Paulista de Medicina. Programa de Pós-Graduação em Cirurgia Plástica São Paulo2010
13 Von Atzingen DANC, Gragnani A, Veiga DF, et al. Gel da casca de Musa sapientum verde no reparo de lesões operatórias em ratos. Acta Cir Bras 2011;26(05):379-382

14 Von Atzingen DANC, Mendonça ARA, Filho MM, et al. Repair of wounds in rats: gel with the green peel of Musa sapientum $10 \%$. Asian Journal of Science and Technology 2017;08(08):

15 Von Loesecke HW. Chemical changes during ripening banana. Chem Physiol Technology 1950;(04):67-118

16 Beitz J, Gerlach M, Ginsburg P, et al. Content validation of a standardized algorithm for ostomy care. Ostomy Wound Manage 2010;56(10):22-38

17 Stelton S, Zulkowski K, Ayello EA. Practice implications for peristomal skin assessment and care from the 2014 world council of enterostomal therapists international ostomy guideline. Adv Skin Wound Care 2015;28(06):275-284, quiz 285-286

18 Chilida MS, Cardozo IF, Lima RLT, Silva MCR, Santos PJ. Custo com equipamentos especializados para estomas: estudo em um serviço do interior do estado de São Paulo. Estima Brazilian J Enterostomal Therapy 2008;6(04):x

19 Mandelbaum SH, Santis EP, Mandelbaum MHS. Cicatrização: conceitos atuais e recurso auxiliaries - Parte II. An bras Dermatol. Riso 2003;78(05):525-542

20 Loyola ABAT, Fernandes RV, Mendes JVB, et al. Antimicrobial Action and Scaring of $10 \%$ Green Banana Shell in Chronic Wounds. Open J Med Microbiol 2018;8:47-55

21 International Ostomy Association (IOA) Declaração Internacional dos Direitos dos Ostomizados. [página na Internet]. [acessado 2016 jun 21]. Disponível em: http://www.abraso.org.br/declaracaoioa.htm

22 Ministério da Saúde (BR) Portaria ${ }^{\circ} 400$ de 16 de novembro de 2009. Diário oficial da União. Brasília - DF, 2009 Seção 2009; $1: 41-42$ 